Meta

Journal des traducteurs

Translators' Journal

\title{
Phrasing and Meaning
}

David Shillan

Volume 13, numéro 2, juin 1968

URI : https://id.erudit.org/iderudit/004132ar

DOI : https://doi.org/10.7202/004132ar

Aller au sommaire du numéro

Éditeur(s)

Les Presses de l'Université de Montréal

ISSN

0026-0452 (imprimé)

1492-1421 (numérique)

Découvrir la revue

Citer cet article

Shillan, D. (1968). Phrasing and Meaning. Meta, 13(2), 47-51.

https://doi.org/10.7202/004132ar

Ce document est protégé par la loi sur le droit d'auteur. L’utilisation des services d'Érudit (y compris la reproduction) est assujettie à sa politique d'utilisation que vous pouvez consulter en ligne.

https://apropos.erudit.org/fr/usagers/politique-dutilisation/
Cet article est diffusé et préservé par Érudit.

Érudit est un consortium interuniversitaire sans but lucratif composé de l'Université de Montréal, l'Université Laval et l'Université du Québec à Montréal. Il a pour mission la promotion et la valorisation de la recherche. https://www.erudit.org/fr/ 


\section{Phrasing and Meaning}

It is generally understood that teaching and learning a foreign language is a "skill» subject, or rather, involves success in four partly separate and distinct skills, namely:
WRITTEN LANGUAGE
SPOKEN LANGUAGE
1) understanding it
2) writing it
3) understanding it
4) speaking it

Part of the teacher's task is to work out correctly for his (or his pupils') purpose, the proportion of time and effort to be given to each of these four.

The craft of the translator is also generally recognized as a skill (though some of us may think its skilfulness is underestimated in some quarters). The question I wish to raise concerns the relationship of the translator's skill to the four basic skills of foreign language learning, and the answer I shall give involves me in the statement that Nos 1,2 and 3 all depend finally on No 4 .

It may be that the ideal translator will be one who is so far bilingual as to be ambilingual, by birthright. Such ideal candidates, however, are not sufficiently plentiful to fill all translators' posts, so we must assume that most translators will have had to learn and master as a foreign language one of the two languages in which they are working at any given time.

Many people would assume that to learn to read a written text is, on the whole, the easiest of skills 1 to 4. My own experience, which takes in many years of teaching English as a foreign language, both to students of all ages and to teachers, shows that it is quite possible for an advanced learner of English, armed with adequate vocabulary and syntax rules, to fail to understand, say, a leading article in The Times, or (much worse) to think he has understood it when he hasn't. The same thing of course happens in experiments with machinetranslation: dictionary and syntax programs are not enough - the machine cannot cope, for lack of experience of how the language is used; and what this phrase covers is " the experience of speech ». Such experience cannot be gained by receptive work alone, but must be acquired by production. You learn to speak 
by speaking; but much more than that, you learn fully to understand written English by the effects of your mastery of spoken English.

This statement is certainly true of English in a way that could not be claimed for all languages, as is demonstrated partly by the special use of punctuation in English, in contrast with some languages (of which German is an example) which have certain invariable rules for the comma. English provides many examples of passages showing no punctuation yet unhesitatingly segmented by the Englishspeaking reader according to the correct syntactic and semantic criteria, to produce the meaning which the writer intended. This results from our speech-experience in the way briefly indicated below.

Take an example, drawn from the first text that came to hand: This situation has now changed drastically and for the past year and a half or more the computer has been able to add full typographical capacity to its other achievements. We know at once that the semantic segments we have to consider do not include changed drastically and for the past year or and a half or more, although these are not on the same linguistic level as stereo-typed constructions like has been able or full typographical capacity. How is this done?

The reader re-phrases it thus:

This situation

has now changed drastically

and for the past year and a half or more

the computer

has been able to add

full typographical capacity

to its other achievements.

He has drawn on his experience of speech to feed back, into his silent reading, the tones and stresses which the writer must have had in his mind's ear when he wrote it.

Thus the reader will «sense» an intonational cadence from the «nuclear tone $»$ at drastically, followed by an intonationally neutral element, the conjunction and introducing a new intonational unit starting with the high " head » tone on past year, leading to the next cadence, from the nucleus half, with or more appended as a « tail ».

This may seem theoretical and far from everyday experience, but there are plenty of occasions on which we say aloud some passage of written text in order either to query its meaning or to demonstrate it. The variable factors possible in such a demonstration are stress and intonation.

Here is another example: $A$ middle power such as Canada must be particularly careful to ration its commitments.

A rapid adjustment has to be made to eliminate such «possibilities 》 as as Canada must be or Canada must be particularly careful. This is done by recognizing the lower, parenthetical, tone on which the words such as Canada are "said ». It must be added that these forms are more basic than any differences or regional or class « accent », and can be detected across these.

Rhythm is an outstanding characteristic of the English language. In speech it consists basically of the roughly isochronous stresses which, as the poet Coventry Patmore said one hundred years ago, are like the posts of a chain railing — we fill

$$
\text { Vol. } 13 \underset{\text { Juin }}{-} \mathrm{N}^{\circ} 268
$$


up the intervals between the posts with strings of syllables so chosen that more numerous light ones will fit into the same interval as less numerous heavy ones. Now obviously when speaking French we do no such thing, for French is syllable-timed and not stress-timed. But there must be something very basic about the DING and DONG of alternating stress-points as we find them in English, with an intonational contour carried on them - and should we not indeed expect it, since our two feet move LEFT-RIGHT, and, at a still more basic level, our heart sends its rhythm of systole and diastole throughout our whole organism. Therefore it is not surprising that when we use this simple form of two-beat tone unit as an analytical instrument, we find not only that we can read it into written text without difficulty but we can adapt it to other languages beside English, even if they differ in their system of timing as French (and Japanese) does.

Examining quantities of the bilingual material available in (governmental) English and Canadian French, we can feel this rhythm at work. We can use it as a way of indicating «tonal $»$ features, that the English reader assumes, and sometimes of removing ambiguities which - even if so trivial as the "such as Canada" example quoted above - are a source of translational delay if nothing worse. It is possible to find examples in which the translator's failure to " hear » the phrasing of the text has led to error, and fortunately many more examples in which his use of it, whether conscious or not, has led to translational felicity.

When we apply this unit, the "phrasing ", we discover a curious fact that would not otherwise have come to light: there is a tendency for sentences or self-contained components of sentences, to consist of four or sometimes a multiple of four of these «phrasings ». Suddenly, we find, like M. Jourdain in reverse, that all our lives we have been speaking and writing in " quatrains 》 like the verses of a hymn.

We have already indicated that phrasing-for-phrasing may be a good basis for translation, and we can now suggest that the quatrain is a useful further unit, since it allows for variations a), b) and c) in phrasing correspondences, as shown below.

a) DIRECT

'Any 'nation

'must be concerned

that its oblighations ()

do'not + outrun its capàbilities $\longrightarrow$

$A^{\prime}$ middle 'power

such as 'Canada ()

must be paŕticularly careful

to 'ration its commitments

'Tout'pays

doit 'faire en šorte

que ses èngagements ()

n'éxcèdent pas ses'possibilités.

Une' puissance 'moyenne

comme le 'Canada ()

doit 'veiller 'particulièrement

à 'restreindre ses 'engagements.

b) EXPANDED

The'Workmen's Compensation

La 'Commission 'd'indemnisation

+ Board also maintains sàfety

+ standards

and trains ()

des 'accidents du'travail

'rnine + rescue crews

établit aussi des 'normes +

de + sécurité

et s'oc̀cupe ()

de 'former des équipes + de + secours aux minineurs ().

Vol. $13-\mathrm{N}^{\circ} 2$ 
c) TRANSPOSED

In a 'pioneer àrea and as 'long as that area is dépendent upon p̀rimary resources 'this is the càse
'Cela se constate

dans les régions ǹouvelles

aussi 'longtemps qu'elles dépendent de l'éxploitation de leurs ressources + primaires.

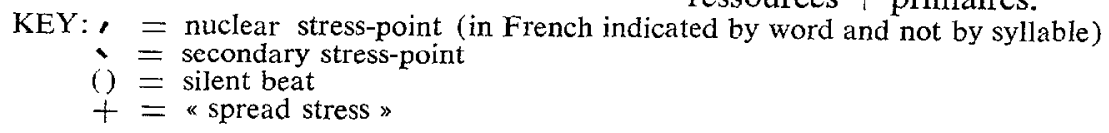

It is the need for plunging deeply into the articulatory experience of producing speech in the languages to be used, disengaging their characteristic rhythmic habits, and mastering the intonational implications that the native-speaker takes for granted.

If we have started learning these languages by old-fashioned methods we shall have a much harder task than if we had been introduced to the foreign language in a living way through speech, and with special exercises to instil the characteristic rhythms. (Nursery rhymes are a particularly favourable way of doing this for English, and I find that they are readily accepted by at least those adults who are teachers of children!) Proverbs have a naturally rhythmical cast, which is part of their essential form as orally-transmitted wisdom for everyday life.

Together with the basic pulse of the natural rhythm of the language, it is of great importance to master the essential intonational equipment, so as to know with certainty, for instance, the way in which English states or rather implies a contrast by use of stress carried on an extra high or an extra low tone, and the different levels of tone used for principal and parenthetical utterances, of varying degrees of importance to the structure of the sentence and the paragraph.

By perceiving the rhythm we enter into the stream of the writer's utterance in the source language. We can catch from the stress-points the semantic nodes on which the message hangs. Pushing syntax back out of the centre of focus, i.e. simplifying it, we get the text into a fresh focus.

Before and during work now in progress for N.R.C., the Cambridge Language Research Unit under Margaret Masterman has shown experimentally that the most close-packed summary of a passage is usually that contained in the principal stress-points, i.e. in English the "nucleus » found at or near the end of each tone-unit. The secondary stress-points (or « head » stresses, nearer to the beginning of each tone-unit) provide a much less informative summary; but the two sets together give a very useful outline semantic structure.

It is difficult in a short quotation to demonstrate this stress-point message summary, but here is an example of English text reduced to stress-points:

Politically justifiable technical disadvantages

U.N. Forces deprived highly developed resources

big powers except external + airlift. 
French text in full:

Du point de vue politique de sérieux motifs légitiment ce recrutement*. Mais du point de vue technique, il est regrettable que les Forces des Nations unies se voient privées des ressources immenses des grandes puissances à l'exception toutefois du transport aérien extérieur.

The central quatrain of the English text (which consisted of six phrasings) was: this has its technical disadvantages

once the U.N. forces were deprived

of the highly developed resources

of the big powers.

BIBLIOGRAPHIE

Hul TZEN, L.S., "Information Points in Intonation ", Phonetica, 4 (1959),

SHILlaN, D., Spoken English, Longmans, Green, London, 1954-1965; teaching tapes: Longmans, 1966.

David Shillan

* The French version uses a noun instead of a pronoun to link back to the theme of the preceding sentence. 